\title{
Deployment of service-learning as a pedagogy for social transformation
}

\section{J. Dzinekou, P. Sergon}

Tangaza University College, Kenia

\section{G. Mureithi}

University of Eldoret, Kenia

\begin{abstract}
Teaching is not only a traditional role of universities, but it remains one of the most critical missions of them. The pedagogy used in teaching determines if learning will be transformational or just transactional. Transactional learning has continually increased university graduates who become a problem to the community instead of being a source of solutions to the community problems. This study introduces service-learning as a transformational learning pedagogy that empowers students to identify problems in their community and enables them to work with the community as co-creators to solve the myriad challenges that the communities battle with daily. The study provides empirical evidence of how the service-learning model is used as an education pedagogy in the informal settlements of Nairobi to train slum dwellers in civic education and development. The study adopted a qualitative approach. The study's findings demonstrate that service-learning enables students to acquire knowledge and skills to deploy in their communities. It provides evidence on how service-learning can be modelled for transformative education. The study results reveal how servicelearning as a teaching pedagogy can contribute to students' personal transformation and the social transformation of the community.
\end{abstract}

\section{Keywords}

Service-learning, action-learning, circle of praxis, community engagement, social transformation.

Fecha de recepción: 24/XI/2021

Fecha de aceptación: 9/XII/2021 


\section{Despliegue del aprendizaje-servicio como pedagogía para la transformación social}

\section{Resumen}

La docencia no es solo un papel tradicional de las universidades, sino que sigue siendo una de sus misiones más críticas. La pedagogía utilizada en la enseñanza determina si el aprendizaje será transformacional o simplemente transaccional. El aprendizaje transaccional ha aumentado continuamente y los graduados universitarios se convierten en un problema para la comunidad en lugar de ser una fuente de soluciones a los problemas de la comunidad. Este estudio presenta el aprendizajeservicio como una pedagogía de aprendizaje transformacional que permite a los estudiantes identificar problemas en su comunidad y les permite trabajar con la comunidad como cocreadores para resolver los innumerables desafíos con los que las comunidades luchan a diario. El estudio proporciona evidencia empírica de cómo el modelo de aprendizaje-servicio se utiliza como una pedagogía educativa en los asentamientos informales de Nairobi para capacitar a los habitantes de los barrios marginales en educación y desarrollo cívico. El estudio adoptó un enfoque cualitativo. Los hallazgos del estudio demuestran que el aprendizaje-servicio permite a los estudiantes adquirir conocimientos y habilidades para implementar en sus comunidades. Proporciona evidencia sobre cómo el aprendizaje-servicio puede modelarse para la educación transformadora. Los resultados del estudio revelan cómo el aprendizaje-servicio como pedagogía de la enseñanza puede contribuir a la transformación personal de los estudiantes y la transformación social de la comunidad.

\section{Palabras clave}

Aprendizaje-servicio, aprendizaje acción, círculo de praxis, participación comunitaria, transformación social. 


\section{Desplegament de I'aprenentatge servei com a pedagogia de transformació social}

\section{Resum}

La docència no només és una funció tradicional de les universitats, sinó que continua sent una de les missions més crítiques d'aquestes. La pedagogia utilitzada en l'ensenyament determina si l'aprenentatge serà transformacional o només transaccional. L'aprenentatge transaccional ha augmentat contínuament i els graduats universitaris es converteixen en un problema per a la comunitat en lloc de ser una font de solucions als problemes de la comunitat. Aquest estudi introdueix l'aprenentatge servei com una pedagogia d'aprenentatge transformacional que capacita els estudiants per identificar problemes a la seva comunitat i els permet treballar amb la comunitat com a cocreadors per resoldre la infinitat de reptes amb què les comunitats lluiten diàriament. L'estudi proporciona proves empíriques de com s'utilitza el model d'aprenentatge servei com a pedagogia educativa als assentaments informals de Nairobi per formar els habitants dels barris marginals en educació i desenvolupament cívic. L'estudi va adoptar un enfocament qualitatiu. Els resultats de l'estudi demostren que l'aprenentatge servei permet als estudiants adquirir coneixements i habilitats per implementar-los a les seves comunitats. Proporciona proves sobre com es pot modelar l'aprenentatge servei per a l'educació transformadora. Els resultats de l'estudi revelen com l'aprenentatge servei com a pedagogia docent pot contribuir a la transformació personal dels estudiants i a la transformació social de la comunitat.

\section{Paraules clau}

Aprenentatge servei, aprenentatge acció, cercle de praxis, compromís comunitari, transformació social. 


\section{Introduction}

A pedagogy for the transformation of the local community requires that community members are active participants in initiatives that concern them. Transformative education appreciates that the community is the custodian of a wealth of knowledge and experience that should be valued in any engagement. Service-learning has advanced the pedagogical approach of knowledge and practice exchange between the community and learners. This opportunity provides ground for mutual learning where the learners apply their skills to help the communities while tapping into the knowledge and wisdom of the communities. The outcome of this engagement is the co-creation of knowledge between universities and communities.

In this paper, we explore the effectiveness of the service-learning pedagogy, its contribution to community actions, and subsequently set in motion a process of social transformation. We highlight the transformations that occurred in the students and the communities as a result of service-learning. We present the experience of University Mtaani (UM) - University in the slums-using service-learning as a learning pedagogy. We use the case of the UM and the engagement of students in the local community in the informal settlements to provide evidence of the transformative power of service learning for both the learners and the communities. This study highlights that the role of academic institutions in transformative learning is to provide a platform for learners and the local community to engage in transformative action. In this engagement, the university's role is a catalyst for unlocking the community's potential.

\subsection{Background of University Mtaani}

University Mtaaniis run by the Institute for Social Transformation (IST) of Tangaza University College (TUC). Tangaza is a constituent college of the Catholic University of Eastern Africa in Kenya. The program is intended to bridge the gap between universities and the marginalized communities hence the informal label, University Mtaani, meaning, "University in the Slum". It is focused on Nairobi informal settlements, particularly Huruma, Mathare, and Korogocho slums. The concept of University Mtaani is based on an approach that takes higher education closer to the people in informal settlements. The program seeks to create a new consciousness in slum dwellers so that they can work towards their own social transformation. The UM hinges its education concept on three main principles: (1) taking university education closer to the people; (2) using an educational approach that is multidimensional, blending classroom learning and community dialogues; and (3) engaging students in generating knowledge through their interaction with the community.

The three-tier approach constitutes UM's methodology of service-learning, which takes a cyclic form. Cyclic in that 
learning taking place in class

transforms the learners, who use their skills to transform their communities by facilitating community mobilization and dialogues meant to address specific issues of the communities.

\subsection{Service-learning}

Service-learning is defined by Taggart and Crisp (2011, p. 25) as "a teaching and learning strategy that integrates meaningful community service with instruction and reflection to enrich the learning experience, teach civic responsibility, and strengthen communities". Service-Learning contains two main elements: engagement within the community (service) and reflection on that engagement (learning) (Preradovic, 2015). This means that communitybased service activities are paired with structured preparation and student reflection. Service-learning uniquely offers direct application of theoretical models to real-world or community realities, thereby allowing students to synthesize course material in more meaningful ways (Clevenger-Bright et al.,2012).

Unlike the traditional learning styles, such as the lecture method that exhibit many limitations, this form of learning actively involves students and the community while also advancing the goals of a given curriculum (ClevengerBright et al., 2012). Gibson et al., (2011) note that traditional learning methods are characterized by passive learning, memorization of factors, and decontextualized from lived experiences.
The service-learning model is typically a course-based, credit-bearing educational experience in which students (a) participate in an organized service activity that meets identified community needs and (b) reflects on the service activity in such a way as to gain further understanding of course content, a broader appreciation of the discipline, and an enhanced sense of civic responsibility (Bringle \& Hatcher, 1995).

As a process, therefore, servicelearning is premised on the understanding that it is a service that meets the needs of the community and is coordinated with an educational institution. For academic purposes, service-learning is meant to be integrated into and to enhance the core academic curriculum, allowing structured time for the students to reflect on the service experience (Billig, 2000) and, finally, it provides the opportunity to demonstrate their project openly and publicly as a form of authentication (Jenkins \& Sheehey, 2011).

\subsection{Circle of Praxis}

The circle of praxis is approach to service-learning. The circle of praxis is a pedagogical method that involves reflection and action. Its main objective is to assist learners in gaining knowledge and skills to transform society. As such, the circle of praxis is essentially a pedagogy of transformative education (Klein et al., 2018). The circle of praxis is an iterative process that includes four steps: insertion/immersion, descriptive 
analysis, normative analysis, and action planning (Headly, 2018; Klein, 2013;

Klein et al., 2013).

Figure 1. Circle of Praxis

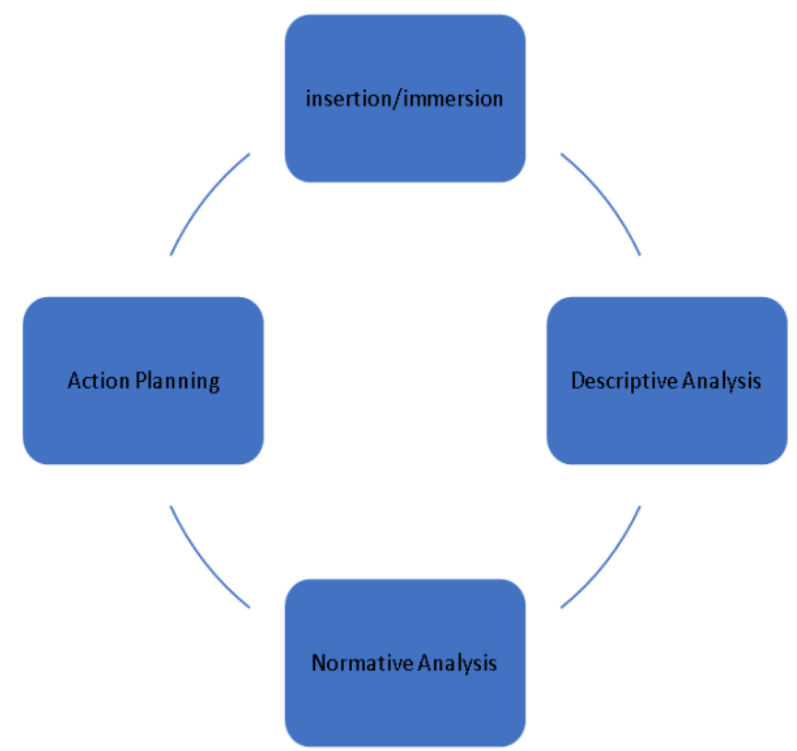

Source: own elaboration based on Klein et al., (2013)

In the first step, learners are exposed to actual problems. This step is referred to as insertion or immersion.

Experience can be either direct or indirect. Direct immersion can be attained through service-learning, community engagement, and immersion trips (Klein et al., 2013). As such, experiential engagement achieved through direct or indirect immersion is a key step in transformational learning.

The second step involves a descriptive analysis of the experiential data. It is a rigorous academic inquiry into the root cause of social issues (Klein et al., 2018). It involves a vigorous analysis of the systematic and structural causal factors that may include social, economic, and political aspects (Klein, 2013).

The normative analysis is a critical interpretation that examines the different worldviews, religious perspectives, and philosophical assumptions held by learners. Normative analysis promotes a critical reflection of existing norms (Klein, 2013).

Through these four steps, the circle of praxis leads learners to a shared journey of self-reflection, critical analysis, and planning for social transformation (Headley, 2018). The four steps lead learners into reflection and action, which are ultimately directed at social structures that require transformation. This implies that the circle of praxis facilitates the awakening of learners' critical consciousness.

\subsection{Social transformation}

Social transformation (ST) implies a fundamental change in society (Khondker \& Schuerkens, 2014), and it refers to the process of change in institutionalized relationships, norms, values, and hierarchies over time. Social transformation is the outcome of the people developing new consciousness that enable them to gain new insights to become agents of transformation in their situation. The issue of agency is central to the process of social transformation.

Transformation presumes a change with positive significance, entailing a 
progression towards the improvement of quality of life. Indicators of quality of life include not only economic growth but also systems such as education, healthcare, political structure, environmental care and leisure activities that safeguard the "capabilities" (Nussbaum, 2003) for the functioning of all members of a given society or a nation in order to enjoy wellbeing. Transformation through education requires an innovative approach that totally departs from mere classroom learning. In other words, transformative education requires a participatory pedagogy that makes the learner and community the protagonist of the learning process and development agenda.

\section{Methodology}

The study used community based participatory impact assessment. This approach allowed active participation of the students and the community in the assessment. It also assisted in evaluating how service-learning in UM has led to social transformation in the community.

The study adopted the qualitative research design. The design was chosen because it enabled the researchers to dive deeper and examine the opinions and motivations of the participants.

Data was collected through interviews, focus group discussions (FGD), historical documents, and audio materials from recordings. A total of seven community leaders were interviewed in-person. Six alumni groups and six community focus groups were identified and they each comprised of five to twenty participants. The FGDs were organized as group meetings of one and a half hours. Secondary data, such as desktop data was utilized, also data was collected from historical reports (20122019).

The areas of focus in this study were various informal settlements in Nairobi, Kenya. These were: Huruma, Mathare, Umoja, Kariobangi, Dandora, Korogocho, Kayole, and Kibra.

\subsection{Findings \& discussions}

The study findings revealed that service-learning pedagogy adopted in the DCDE program of University Mtaani resulted in the transformation of the students and the community.

\subsection{Impact of service-learning pedagogy on students}

The assessment reviewed the contribution of the service-learning pedagogy to the students' personal, professional, and social life. The training empowered students with skills for community dialogue. Transformation of students was measured against the skills attained, ability to carry out community dialogues and selfassessment of personal growth. The following section details findings relating to the transformation of the students.

\subsubsection{Development and practical use of dialogue skills}

Students attested to the effectiveness of the pedagogy employed by UM. They 
affirmed that the program empowered them with skills in community dialogue and engagement. One of the student participants (SP) put it this way:

- "I think one of the unique components that Tangaza has compared to other universities is that after you've read the theoretical part now, you have to actually do it practically. And when we discuss the issues of community dialogues or community issues... you need to do it both theoretically and practically" (SP \#2).

A further appraisal is offered on the importance of the practical approach to learning. Student participant \#3 observed that:

- "Through the DCDE, we have come to learn that solutions of the problems affecting the community are within the community itself. So, through this community dialogue skill, you are able to let the people come out and bring what they think can be solutions to their problems" (SP \#3).

\subsubsection{Facilitation and communication skills}

Another student shared her enthusiasm for the knowledge and skills she gained on how to facilitate community activities and to communicate and present her ideas. She highlighted that;

- "Facilitation and communication skills: I learned those; how to write proposals and about project management. I have mobilised women who are now being taught how to make yoghurt, soap etc. And we are helping them on how they can organise themselves to access funds".

\subsubsection{Change in students' attitude}

Drawing from the data collected, students shared how their experience in practical community work challenged their views, attitudes and even behaviour. A student pointed out that;

- "An attitude-changing lesson from the community was that, when you go to these people, (community) do not take it for granted that they are as they look".

Similarly, another student emphasised by adding:

- "What I learned is that as a leader, the way you approach these women... the tone you take with them is the way it will bounce back to you... the prevailing attitude depends on the leaders".

In general, the findings show that students developed skills that build in them the capacity to engage meaningfully with the community. Gleaning from the information provided by participants, these skills are not random; they are specific and tailormade to address social challenges and procure the changes needed. During the FGDs with the students, the group from Mathare, for instance, had this to say: 
- "DCDE is a diverse program that taught us entrepreneurship, human rights and many other lessons. The program is tailored such that it enables and empowers the learner to engage and help the community. The program has led to changes in attitude, linkages and knowing where you are going".

The findings indicate that the benefits of the DCDE program to students are life-changing and sustainable. The program helps students identify their passion and the areas of community engagement they would like to pursue. Moreover, the findings indicate that the use of service-learning pedagogy has developed the students' competence to work closely with the communities in identifying challenges within, in finding solutions to these problems and in enabling the communities to be part and parcel of these processes. The education attained is not only transactional, but as the findings reveal, the education brings transformation first of all to the students, then this transformation is also observed in the community as a result of the student- community engagement.

\subsection{Impact of Service-Learning Pedagogy on the Community}

A myriad of changes was also observed in the communities once the students began their community engagements. These changes are significant in highlighting how service-learning pedagogy results in transformation. The findings on the impact of the DCDE program on the community are evidence of what education for transformation can do. These findings reveal that the service-learning pedagogy enhances social transformation.

\subsubsection{Change attitude of community members}

Change in attitude and behaviour was two-sided. Student participants demonstrated that the change in their approach translated into a change in their relationship with the community and thus better outcomes. The change in the attitude of the students influenced how the students related to different people in the community. In return, the community members responded positively to the students' call.

One student summed up the change in the attitude of the community members by detailing that:

- "There is a change in community attitude...youths would say they had no jobs... jobs are for the older people..." But from the point they were engaged, the youth implemented many action plans. During that time, we did a program on 'Usafi, JukumuLetu' which really changed the attitude of the community towards garbage management. Now, people no longer throw garbage on the roads".

\subsubsection{Improved Hygiene}

Over and above the processes and progress that UM has accomplished through community dialogues, some 
permanent landmarks or traces are visible in the community as a testimony of the sustainable development that the Institute for Social Transformation advocates for. Some of the observable results include improved hygiene in the community after the dialogues in hygiene. Respondent \#3 from Kariobangi noted that;

- "It was out of those dialogues in 2012/2014 that we did what we call 'Usagi, JukumuLetu' project, and we realised that the sewer line in Kariobangi was very narrow. Right now, we have the sewer line in Kariobangi expanded with the support from the UM. Landlords are now connecting to the new sewer line".

\subsection{Rise of Community-Based Organisations}

Another significant contribution of the presence of UM in the community is the emergence of community-based organizations (CBOs) that follow in the footsteps of Tangaza to bring change in the community. A student participant confirms that some of the community dialogues gave rise to CBO's. Community members took the onus of starting and running their own organizations. Besides, students of UM got the opportunity and courage to practice the knowledge they gained by starting their own organizations. Another student lauded the outcome of the student-community engagements by explaining that:

- "A major significant change in the community is self-realization and teamwork. They no longer wait for someone else to do their work. Idle zones have reduced, they are creating jobs for themselves and not relying on their leaders for handouts".

\subsubsection{Reduction of the 'dependency syndrome'}

With regards to 'dependency syndrome', which is often associated with people in informal settlements, community dialogues have had a positive effect of gradually drawing the community out of this mindset. Among the observations made is that:

- "People are now able to understand that they can handle problems themselves, So, their attitude towards their abilities is changing positively" (Cohort \#2, respondent \#1).

Another participant added:

- "We started seeing that the community has a positive attitude towards the problems they have, and they are ready to take in as they have the solutions in their hands. For example, when I took part in sanitation dialogue, the community was ready to take part in community clean-ups, and people turned up in large numbers, and that is a positive change" (Cohort \#2, respondent \#6).

Equally, another participant observed that the communities are motivated to freely attend the community dialogues 
without asking for payment because they have realized that the dialogues are beneficial to them and not the organizers.

- "Our people are able now to work on themselves even without the money they used to get from NGOs. For example, we've gone to several places whereby people acknowledge that they only attended workshops because there was money, but now when they hear it is University Mtaani students, they normally come in big numbers because they know what they will get from us compared to what they used to get where they used to get money" (Cohort \#2, respondent \#2).

From the assertions presented by the students, it can be seen that the niche of UM lies on two key pillars; the first is the formation of students themselves, which does not only impart skills but brings out the best in them. The second pillar is the hands-on approach that locates students in their own communities to practically apply skills learned. The service-learning approach produces multi-prong benefits; the transferability of knowledge from the classroom to the community, instilling responsibility in students as change agents and gauging the relevance of the education system and content to meet the development needs of society.

\subsubsection{Knowledge on Civic Rights}

Community members have acquired knowledge about their civic rights because UM has helped mobilize them to participate in county meetings and understand how important their involvement in these meetings is. One of the participants also highlighted the role of University Mtaani in initiating a paralegal group that helps the community uphold their rights.

- "Through the dialogues with University Mtaani, a paralegal organization was created. It has a legal office in Kariobangi and Korogocho. The organisation advocates for the rights of people. Now people know how and where to get a lawyer" (resp. 4- Kariobangi W.M)

According to the key informants, their experience with UM has been very engaging and meaningful to the communities they serve. Information gathered from the community leaders demonstrates that UM is not only present as a structure located in the middle of a slum, its service-learning pedagogy has transformed the lives of the people.

In regard to the achievements of UM in the slums, the Ward administration of Kiamaiko gave a thumbs-up to the contribution of UM and in his words:

- "University Mtaani has created awareness on the need for public participation especially in Kiamaiko ward. Also issues of environmental conservation and social accountability have been highlighted. UM has also done trainings on cleanliness and environmental management impacting positively on the community" (Kiamaiko, Ward 
Administrator).

\section{Conclusions}

Through service-learning, the community becomes a platform through which the students serve instead of reading, and this challenged them out of their comfort zones. Through all these, service-learning creates a sense of social responsibility in the students. Service-learning pedagogy enables students to develop community ties through which they apply the knowledge learnt in the classroom and through which they serve the community. Moreover, service-learning shifts the university's culture from traditional teaching pedagogies that are passive and decontextualized from lived experiences. It leads the university and its instructors to emphasize their teaching on active students' engagement. In conclusion, therefore, service-learning creates a dynamic, interactive relation between the university, students and the community. It impacts the university, the instructors, the students and the local community.

\section{References}

Billig, S. H. (2000). Research on K-12 school-based service-learning: The evidence builds. Phi Delta Kappan, 81(9), 658-664.

https://digitalcommons.unomaha.edu/c gi/viewcontent.cgi?article $=1003 \&$ contex $\underline{\mathrm{t}=\text { slcek} 12}$

Bringle, R., \& Hatcher, J. (1995). A service-learning curriculum for faculty. Michigan Journal of Community Service Learning, 2(1), 112-122. http://hdl.handle.net/2027/spo.323952 $\underline{1.0002 .111}$

Clevenger-Bright, M., Hays, K., Henricksen, L., Hlebain, D., Maglalang, M. Packard, M., Pursch Cornforth, K., \& Raftus, D. (2012). Service learning.

Page summaries a document that was the result of a learning community hosted by the Center for Teaching and Learning (CTL).

https://teaching.washington.edu/topics Lengaging-students-in-learning/servicelearning/

Gibson, M., Petra, H., Long, B., \& Sampson, G. (2011). Reflective practice in service-learning: possibilities and limitations. Education \& Training, 53(4), 284-296.

Headley, S.D. (2018). A praxis-based approach to theological training in Capetown. Theological Studies, 74(3), 1-7.

Jenkins, A., \& Sheehey, P. (2011). A checklist for implementing servicelearning in higher education. Journal of Community Engagement and Scholarship, 4(2), 1-9. https://digitalcommons. northgeorgia.ed u/jces/vol4/iss2/6

Khondker, H., \& Schuerkens, U. (2014). Social transformation, development and globalization. Sociopedia.isa, 1-14. https://doi.org/10.1177/205684601423

Klein, M. (2013). Cell Phones, T-shirts and Coffee: Codification of Commodities in Circle of Praxis Pedagogy. Peace Studies Journal, 6(1), 31-45. 
Klein, M., Finnegan, A., \& Nelson-

Pallmeyer, J. (2018). Circle of Praxis

Pedagogy for Peace Studies. Peace

Review: A Journal of Social Justice,

30(3), 270-278.

https://doi.org/10.1080/10402659.201

8.1495802

Nussbaum, M.C. (2003). Capabilities as fundamental entitlements: Sen and

social justice. Feminist Economics, 9(23), 33-59.

Preradovic, N. (2015). Service-

Learning. In M. Peters (ed.).

Encyclopedia of Educational Philosophy

and Theory. 1-6.

https://www.researchgate.net/publicati

on/304196465 Service-Learning

Taggart, A., \& Crisp, G. (2011). Service

learning at community colleges:

Synthesis, critique, and

recommendations for future research.

Journal of College Reading and

Learning, 42(1), 24-44. 